\title{
Marketing Library and Information Services
}

\author{
Prakash Dongardive \\ Department of Information Science, CNCS, Mekelle University, Ethiopia
}

\begin{abstract}
The interest in marketing has tremendously increased over the past few decades in libraries like other service centers; education, health, transportation, insurance, banking, etc. For a long time, we librarians and information professionals had enjoyed a supplier's market and we lost our interest in working for our customers, and yet we want customers to come back. However, we should always keep in mind that only satisfied customers come back and there are greater chances that an unsatisfied customer will find some other suppliers of information to meet their information need. Today marketing is whole organization concept and organization wide philosophy, which requires years of continual work. It is a way of working and a way of serving the customers in which every activity is committed to customer satisfaction. Marketing of library services is the effective execution of all the activities involved in increasing satisfaction of users by providing maximum value to them. It is a total solution for library and information centers. There have been enormous developments in marketing of library and information services around the world. The present paper explores the discipline of marketing of library services as a new academic subject in library and information education.
\end{abstract}

Keywords: Information Marketing, Library marketing, Library economy

\section{Introduction}

Marketing management is a business discipline which is focused on the practical application of marketing techniques and the management of a firm's marketing resources and activities which today being applied in Library and Information Science. Rapidly emerging forces of globalization have led firms to market beyond the borders of their home countries, making international marketing highly significant and an integral part of a firm's marketing strategy. Marketing managers are often responsible for influencing the level, timing, and composition of customer demand accepted definition of the term. Marketing manager can vary significantly based on a business's size, corporate culture, and industry context. Libraries and Information centers have large consumer and Information as a commodity, librarian and Information officer serve as marketing manager in this context, the libraries may act as the overall general manager of his or her assigned product to create an effective, cost-efficient marketing management strategy, firms must possess a detailed, objective understanding of their own business and the market in which they operate. In analyzing these issues, the discipline of marketing management often overlaps with the related discipline of strategic planning. Libraries and information centers are facing a time of unprecedented change and challenge. Recent technological developments are creating new forms of information, new sources of information and new ways of providing information by passing traditional institutional like libraries. There has been an increasing pressure on libraries to mobilize resources and become selfreliant. Library users are transforming into customers with rising expectations, diverse needs and wants, and choices. Now, the real challenge for library and information professionals is not to manage the collection, staff and technology but to turn these resources into services. The conception of services has also changed, from basic to value added, from staff assisted to self -service, from in-house to outreach, from free to priced, from reactive to pro-active, and from mass customization to individualized service. As in such an environment librarians are finding new ways of serving users or customers effectively and efficiently. The principles of marketing have gradually been accepted both as relevant and beneficial to the library environment. Marketing provides an opportunity to see as to how they can offer effective and efficient services to their users or customers. There have been many developments at international level, which have directly or indirectly contributed for the growth and development of marketing in library services in global arena.

\subsection{Definition to marketing}

"Marketing is the analysis, planning, implementation and control of carefully formulated programs designed to bring about voluntary exchanges of values with target markets for the purpose of achieving organizational objectives. It relies heavily on designing the organization's offering in terms of the target market's needs and desires and as using effective pricing, communication, and distribution to inform, motivate and serve the markets."

- Marketing is a managerial process involving analysis, planning, implementation and control.

- Marketing is concerned with carefully formulated programs - not random actions - designed to achieve desired responses.

- Marketing seeks to bring about voluntary exchange.

- Marketing selects target markets and does not seek to be all people.

- Marketing is directly correlated to the achievement of organizational objectives.

- Marketing place emphasis on the target market's (consumer's) needs and desire rather than on the producer's preferences

\section{Marketing Services}

Services marketing are a sub field of marketing, which can be split into the two main areas of goods marketing (which includes the marketing of fast moving consumer goods (FMCG) and durables) and services marketing. Services marketing typically refer to both business to consumer (B2C) and business to business (B2B) services, and include marketing of services like telecommunications services, financial services, all types of hospitality services, car rental services, air travel, health care services and professional 
services. The range of approaches and expressions of a marketing idea developed with the hope that it be effective in conveying the ideas to the diverse population of people who receive it. Services are economic activities offered by one party to another. Often time-based, performances bring about desired results to recipients, objects, or other assets for which purchasers have responsibility. In exchange for money, time, and effort, service customers expect value from access to goods, labor, professional skills, facilities, networks, and systems; but they do not normally take ownership of any of the physical elements involved.

\subsection{Characteristics of marketing services}

\subsubsection{Intangibility}

Services are intangible and do not have a physical existence. Hence services cannot be touched, held, tasted or smelt. This is most defining feature of a service and that which primarily differentiates it from a product. Also, it poses a unique challenge to those engaged in marketing a service as they need to attach tangible attributes to an otherwise intangible offering.

\subsubsection{Heterogeneity/Variability}

Given the very nature of services, each service offering is unique and cannot be exactly repeated even by the same service provider. While products can be mass-produced and be homogenous the same is not true of services. e.g.: All burgers of a particular flavor at McDonalds are almost identical. However, the same is not true of the service rendered by the same counter staff consecutively to two customers.

\subsubsection{Perish ability}

Services cannot be stored, saved, returned or resold once they have been used. Once rendered to a customer the service is completely consumed and cannot be delivered to another customer. e.g.: A customer dissatisfied with the services of a barber cannot return the service of the haircut that was rendered to him. At the most he may decide not to visit that particular barber in the future. Inseparability/Simultaneity of production and consumption: This refers to the fact that services are generated and consumed within the same time frame. E.g.: a haircut is delivered to and consumed by a customer simultaneously unlike, say, a takeaway burger which the customer may consume even after a few hours of purchase. Moreover, it is very difficult to separate a service from the service provider. E.g.: the barber is necessarily a part of the service of a haircut that he is delivering to his customer.

\section{Marketing Entity}

\subsection{Goods}

Physical goods that may be manufactured produced in farms or mined. These account for the bulk of the marketing efforts in most of the countries.

\subsection{Services}

These are intangible products that involve performing some service for the customers. This may be service performed on the customer, like a haircut, on customer's possessions, like servicing of car, or for the customer, like screening of a movie. Services account the maximum marketing effort after products in most of the countries. In many developed countries the volume of services has exceeded that of goods.

\subsection{Events}

Time based shows such as New Year celebration, or a sporting event.

\subsection{Experiences}

Experiences which results from a combination of products and services. The customer is interested in the total experience such as an organized holiday tour package rather than the individual products and services included in the package.

\subsection{Persons}

Like marketing of a celebrity or of a candidate in a public election.

\subsection{Places}

Like cities, state, nations, for purposes such as attracting tourists and investment.

\subsection{Properties}

This could be physical properties like real estate or intangible rights in properties.

\subsection{Organizations}

This basically refers to building positive image of organizations, such as companies, universities, and charitable organizations.

\subsection{Information}

Books are the traditional means of selling information, but there is many other type of information marketed. For example market intelligence, economic analysis and mailing lists.

\subsection{Ideas}

Every market offering includes a basic idea. In addition ideas may be marketed by themselves. For examples, some religious bodies try to promote their ideas of what constitutes the right behavior.

\section{Need of marketing in Information services}

\subsection{Management of Libraries}

Due to explosion of information at global level, the more information available in the market, therefore management of libraries is necessary to meet information needs of users. "The world in which libraries exist has changed dramatically. It moves faster, relies on technology and competes more intensely. Fearful that change may threaten 
our existence, we must look to marketing to help us manage better"

\subsection{Commitment to Customer Satisfaction}

In context of library services area, the users are fund providers, patrons, employees, etc. As such, satisfaction of the customer is of primary concern in the marketing process and the entire ethos and shared values of the organization owe the responsibility of satisfying the customer. The library and information center is not a profit-oriented organization in marketing. The increased customer satisfaction will result in the increased willingness to use and pay for the services offered. Hence, the customer's satisfaction has a direct link with the support we get for the library and information services.

\subsection{Understanding Customers}

When we talk about customers, we have some very fundamental questions to ask, questions that affect any and everything else we do. Such questions include: Who are the customers? Whom are we trying to serve? What is the interest area? What can we provide to serve these interests? What are the conditions for offering information services and products? How well do we communicate with our users and how they communicate their needs to us? There is a common understanding that who knows better about the library then s/he knows better about its resources, facilities, services, and products particularly in the information era. The most important role of marketing in library and information centre is to find information/products for the customers, not customers for the information/product. We must always remember that no library owns its users to the extent that it determines their likes and dislikes. We must pay attention to users' requirement and preferences.

\subsection{Welcome Again and Again}

We should deal with a smile to the users satisfaction. We should give positive attitude and favorable relationships with users. But they will come again only if their present needs are well met, and in meeting the information needs of users marketing attitude plays a vital role.

\subsection{Libraries need to grow}

According to Ranganathan's 5th law "Library is a growing organism". Due to global information explosion, more information comes every second and today's information is old very fast for tomorrow. Libraries continue to face continuing changes in the environment strategies and outcomes. Good marketing efforts take care of all resources and how it can be done in an efficient way.

\subsection{Improving our Image}

In today's business environment "Librarians who take marketing seriously will earn "street creed" in their organization. This will be benefited to them in career terms, but will also help to accelerate the demise of obstacles and herald the arrival of the focused, business-like, customer led librarian" A good reputation may involve cordial relations with the community, good facilities, high service standard, good discipline, a well-qualified staff and good results. As such, marketing efforts can help us in improving our image through improved services.

\section{Strategic Marketing Planning Process and Marketing Environment}

Strategic planning is a management tool borrowed from the business world that academic libraries are finding useful in looking at their futures and how to manage them. A strategic plan provides a structure for analyzing the current and future opportunities and challenges an organization faces. It forces the library to articulate clearly its vision for what its services will be at a future date, and what its key mission is in relation to its parent university's mission. The plan includes specific goals that would result in the library realizing its vision, the activities that must take place to achieve the goals, and what personnel and financial resources will be garnered and allocated to those activities.

\subsection{Strategic marketing Planning process}

The strategic marketing planning process is a cyclical process that must be a continuing activity of the library undertaking it. It is a data-driven decision making and service quality improvement process that must begin with market research of the target audience, such as undergraduate students. The gathered data must be analyzed to determine what the met and unmet needs of the audience are from the audience's perspective. Objectively gathering and analyzing the data requires the librarians to avoid assuming what the audience perceives, wants, or needs. By avoiding assumptions, and being open to information that may be new or unexpected, librarians can better understand the target audience, better communicate with them, and better meet their current and future needs. The library is better positioned to develop successful communication and service delivery goals, and to design communication tools that are most effective in reaching the target audience. Assessment is an essential part of the strategic marketing planning process, for analyzing measurable outcomes enables the library to improve services and set new, relevant goals for the future.

\section{Marketing Planning Process}

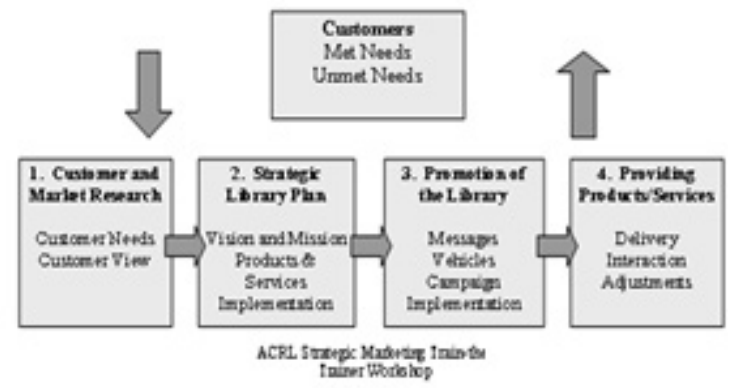

Figure 1: Marketing Planning Process

\subsection{Strategic marketing plan includes}

1) Customer and Market research that generates data on customer needs and perspectives on library service. 
2) The context of current and future opportunities and challenges facing the library that allow it to clarify its vision, mission, and prioritized services.

3) Long-term goals to achieve, such as "Faculty understands the value of the library's role in supporting the campus' teaching mission."

4) Objectives to accomplish, such as "A librarian will contact each new faculty member within the first term of the faculty member's appointment.”

5) The description of the desired elements of the library's image as perceived by others.

6) The most important key messages to deliver frequently and consistently to others through the most appropriate communication methods.

7) Prioritized key audiences, such as library users, campus administrators, government officials, as well as how and when to communicate with them.

8) Implementation of strategies, for delivering key messages and services as appropriate to key audiences.

9) Evaluation for measuring outcome achievement that represents progress toward goals and suggests how to improve communication and service delivery.

10) Incorporating assessment information into market research to adjust and improve the planning and service implementation processes.

\subsection{Marketing Environment}

Marketing environment and types: "Encompass the marketing team within an organization includes all of the outside factors of marketing that on the ability to develop and maintain successful customer relationships with their targeted customer group” Marketing environment is one of the important terms of marketing management. It is external to marketing management and is uncontrollable and ever changing. It consists of Micro environment, Macro environment.

\subsection{Micro environment of Marketing}

It is the job of the marketer to establish good relationship with their micro environment as the success of the company/ organization depends upon the micro environment, ME includes following factors:

\subsubsection{Suppliers}

Suppliers are the persons who provide the company necessary raw material. If the company is not having cordial relations with the supplier then it may result into short run loss in sale and damage the customer relations

\subsubsection{Marketing intermediaries}

They help in promoting, selling and distributing the goods to the ultimate consumer. They include middleman like agents, dealers, whole-sellers, retailers, brokers; physical distribution firms which help the manufacturer in moving the goods from the factory to their destination; warehousing firms which help in storing and protecting the goods; transportation firms which help in moving the goods; market service agencies which help in consultancy, research, advertising etc; financing firms provide help in insuring the risk associated with the buyer.

\subsubsection{Customers}

As likes of customer changes very fast so for the growth of the company the marketer must keep studying the customer related factors and their demand regular basis.

\subsubsection{Competitors}

It is necessary for the marketing manager to have the knowledge about the competitor's status, strength, weakness to take the competitive advantage.

\subsubsection{Public}

The company must have good public relation department to maintain good relations with the public.

\subsection{Macro environment of marketing}

Macro environment is uncontrollable, ME includes following factors;

- Demographic environment: - it includes the life style, income, qualification, age, marital status, sex, family structure etc. so the marketer must have the knowledge about it. Like teenage market, kids market.

- Economic environment: - it means the purchasing power of the consumer the marketer must have the knowledge about the inflation, changing consumer pattern, real income, low saving etc.

- Natural environment: - the marketer must have the knowledge about natural resources, their shortage if any, government policies etc.

- Technological environment: - it is the technology which is changing the life of the people. So the marketer must keep an eye on the changing technology.

- Political environment: - political stability is very important for the growth of any economy it include the law, government agencies etc. marketing decisions are affected by the political environment.

- Legal environment: - the marketer must function as per the legal formalities and should not work against them.

\section{Marketing services and marketing Systems}

The systematic design, collection, interpretation, and reporting of information not currently available, to help managers solve specific marketing problems or take advantage of marketing opportunities. In other words, marketing research is the process of defining a marketing problem and opportunity, systematically collecting and analyzing information, and recommending actions to enhance an organization's marketing activities. It is the function that links the consumer and public to the marketer

\subsection{Importance of marketing research (MR)}

This research helps the marketers or Librarian to make a decision about the product or service. Sometimes a marketer might believe that the new product or service is useful for the customers. However, research may show that customers do not need a product or are meeting their needs with a certain competitor product and so on. Similarly good research strives to provide options for the successful introduction of new products and services. 


\subsubsection{Survive the Competition}

Marketing research helps in ascertaining and understanding competitor information such as their identity, marketing network, customer focus and scale of operations. This helps in surviving and in certain cases, even leaving behind the competition. Moreover, with market research you can also help understand the under-served consumer segments and consumer needs that have not been met.

\subsubsection{Helps to Decide Target Markets}

Research helps provide customer information in terms of their location, age, buying behavior and gender. This helps the marketers zero in on the target markets and customers for their products and services.

\subsubsection{Maximize Profits}

Apart from profit maximizing steps such as item optimization, customer profitability analysis, and price elasticity, marketing research allows you to find out methods that can help you maximize profits. For example, a product's price elasticity research can help you ascertain the impact of an increased price on the sales and the profits of a product. This emphasis on profitability also helps the company's focus to shift from maximizing sales to increasing the profits of a company. This helps the company survive in the long run and maximize its profits.

\subsubsection{Increasing the Sales}

Increasing the sales of your products or services helps a company in maximizing its profits. By understanding the customer's needs, wants and attitude towards the products and determining whether your products fit the bill, marketers can increase their sales. This helps in not only increasing the sales to the target customers and people already using the product but also converting the non users into customer need.

\subsection{Marketing Information System}

"A marketing information system is a continuing and interacting structure of people, equipment and procedures to gather, sort, analyze, evaluate, and distribute pertinent, timely and accurate information for use by marketing decision makers to improve their marketing planning, implementation, and control".

\subsection{Advantages of marketing information system}

1) Organized data collection.

2) A broad perspective.

3) The storage of important data.

4) An avoidance of crises.

5) Coordinated marketing plans.

6) Speed in obtaining sufficient information to make decisions.

7) Data collection and kept in excess of several time of periods.

8) The ability to do a cost-benefit analysis

\section{Consumer buying behavior}

Buying Behavior is the decision processes and acts of people involved in buying and using products.

\subsection{Stages of the Consumer Buying Process}

\subsubsection{Problem Recognition (awareness of need)}

Difference between the desired state and the actual condition. Deficit in assortment of products. Hunger - Food. Hunger stimulates your need to eat, can be stimulated by the marketer through product information - did not know you were deficient? I.E., see a commercial for a new pair of shoes, stimulates your recognition that you need a new pair of shoes.

\subsubsection{Information search}

1. Internal search, memory.

2. External searches if you need more information. Friends and relatives (word of mouth). Marketer dominated sources; comparison shopping; public sources etc. A successful information search leaves a buyer with possible alternatives, the evoked set or call to mind or suggest, Hungry, want to go out and eat, suggested set is;

a) Chinese food

b) Indian food

c) Burger king; same thing in the context of information sources.

\subsubsection{Evaluation of Alternatives}

Need to establish criteria for evaluation, features the buyer wants or does not want. Rank/weight alternatives or resume search. If decide that you want to eat something spicy, Indian gets highest rank etc. If not satisfied with your choice then returns to the search phase. Can you think of another restaurant? Look in the yellow pages etc. Information from different sources may be treated differently. Marketers try to influence by "framing" alternatives.

\subsubsection{Purchase decision}

Choose buying alternative, includes product, package, store, method of purchase etc.

\subsubsection{Purchase}

May differ from decision, time lapse between $4 \& 5$, product availability.

\subsubsection{Post-Purchase Evaluation}

Outcome: Satisfaction or Dissatisfaction. Cognitive Dissonance, have you made the right decision. This can be reduced by warranties, after sales communication etc. After eating an Indian meal, may think that really you wanted a Chinese meal instead.

\section{Marketing segmentation and Marketing Mix}

\subsection{Marketing segmentation}

"Market segmentation is the process of dividing a total market into market groups consisting of people who have relatively similar product needs; there is a cluster/group of needs” A market segment consists of individuals, groups or organizations with one or more characteristics that cause them to have relatively similar product needs. The purpose is to design a $\mathrm{MM}(\mathrm{s})$ that more precisely matches the needs of individuals in a selected market segment(s). 


\subsection{Marketing Mix}

The marketing mix is a business tool used in marketing and by marketing professionals which today being used in Libraries to providing quality services globally. The marketing mix is often crucial when determining a product or brand's offering, and is often synonymous with the four Ps: price, product, promotion, and place; in service marketing, however, the four Ps have been expanded to the seven or eight Ps to address the different nature of services. In recent times, the concept of four Cs has been introduced as a more customer-driven replacement of four Ps. And there are two four Cs theories today. One is Lauterborn's four Cs (consumer, cost, communication, convenience), another is Shimizu's four Cs (commodity, cost, communication, channel). Four Ps: the producer-oriented model of Marketing Mix. The marketer E. Jerome McCarthy proposed a four Ps classification in 1960, which has since been used by marketers throughout the world.

\subsubsection{Product}

Every product is subject to a life-cycle including a growth phase followed by a maturity phase and finally an eventual period of decline as sales falls. Marketers/Library manager must do careful research on how long the life cycle of the product they are marketing is likely to be and focus their attention on different challenges that arise as the product moves through each stage. The marketer must also consider the product mix. Marketers can expand the current product mix by increasing a certain product line's depth or by increasing the number of product lines. Marketers should consider how to position the product, how to exploit the brand, how to exploit the company's resources and how to configure the product mix so that each product complements the other. The marketer must also consider product development strategies.

\subsubsection{Price}

The price is the amount a customer pays for the product. The price is very important as it determines the company's profit and hence, survival. Adjusting the price has a profound impact on the marketing strategy, and depending on the price elasticity of the product, often it will affect the demand and sales as well. The marketer should set a price that complements the other elements of the marketing mix. When setting a price, the marketer must be aware of the customer perceived value for the product. Three basic pricing strategies are: market skimming pricing, market penetration pricing and neutral pricing. The 'reference value' (where the consumer refers to the prices of competing products) and the 'differential value' (the consumer's view of this product's attributes versus the attributes of other products) must be taken into account.

\subsubsection{Promotion}

Represents all of the methods of communication that a marketer may use to provide information to different parties about the product. Promotion comprises elements such as: advertising, public relations, personal selling and sales promotion. Advertising covers any communication that is paid for, from cinema commercials, radio and Internet advertisements through print media and billboards. Public relations is where the communication is not directly paid for and includes press releases, sponsorship deals, exhibitions, conferences, seminars or trade fairs and events. Word-ofmouth is any apparently informal communication about the product by ordinary individuals, satisfied customers or people specifically engaged to create word of mouth momentum. Sales staff often plays an important role in word of mouth and public relations.

\subsubsection{Place}

Refers to providing the product at a place which is convenient for consumers to access. Place is synonymous with distribution. Various strategies such as intensive distribution, selective distribution, exclusive distribution and franchising can be used by the marketer to complement the other aspects of the marketing mix.

\section{Pricing and Communication Strategy}

Pricing: "Price is the value placed on what is exchanged. Something of value is exchanged for satisfaction and utility, includes tangible (functional) and intangible (prestige) factors. Library manager must determine if the utility gained from the exchange is worth the buying power that must be sacrificed. Price represents the value of a good/service among potential purchases and for ensuring competition among sellers in an open market economy. Marketers need to understand the value consumers derive from a product and use this as a basis for pricing a product--must do this if we are customer oriented.

\subsection{Importance of Price to the Marketer/librarian}

1) Often the only element the marketer can change quickly in response to demand shifts. 2) relate directly to total revenue $\mathrm{TR}=$ Price Profits $=\mathrm{TR}-\mathrm{TC}$-effects profit directly through price, and indirectly by effecting the sold, and effects total costs through its impact on the sold, (i.e. economies of scale) 3) Can use price symbolically, emphasize quality or bargain? 4) Deflationary pressures, consumers very price conscious.

\subsection{Factors Affecting Pricing Decisions}

There is considerable uncertainty regarding the reaction to price on the part of buyers, channel members, competitors etc. It is also important in market planning, analysis and sales forecasting.

\subsubsection{Organizational and Marketing Objectives}

Need to be consistent with companies' goals. IE exclusive retailer sets high prices, also consistent with the marketing objectives for the year.

\subsubsection{Types of Pricing Objectives}

Profit, satisfactory profit levels vs. profit maximization. expressed in dollar amount or percent change from the previous period. Market share, pricing objectives used to increase or maintain market share. Cash flow; recover cash as fast as possible, especially with products with short life cycles. Status Quo, maintain market share, meeting competitors prices, achieving price stability or maintaining public image. Survival, accept short term losses necessary for survival. 


\subsubsection{Buyers Perceptions}

How important is price to the target market. Price sensitivity varies among market segments and across different products (i.e. necessary products vs. luxury) Need to know buyers acceptable range of prices and sensitivity towards price changes. Need to gauge Price Elasticity, a measure of the sensitivity of the demand to changes in prices. Percent change in quantity demanded relative to the percent change in price.

\subsubsection{Costs}

In the long run, cannot survive by selling at or below cost. Need to take into account all costs, costs associated with product, with total product line, cost effective and cost benefit strategy.

\subsubsection{Other marketing Mix variables}

All marketing mix variables are interrelated. IE price determines the quality status. Determines the type of distribution (selective/intensive) Affects the margin for wholesalers and retailers. Type of promotion, use price (bargain)

\subsubsection{Channel Member Expectations}

Expect to receive a profit for services performed. Need to keep distributors/retailers happy, avoid conflicts, use exclusive dealing, and avoid discounters. May use price guarantees to assure wholesalers/retailers that the price they pay is the lowest available. Cooperation depends on the equitable distribution of costs and profits within the channel.

\subsection{Communication Strategy}

Marketing communication helps to develop brand awareness, which means that consumers translate product information into perceptions about the product's attributes and its position within the larger market. Businesses also use marketing communication to retain the product's current customer base, and to cement relationships with customers and suppliers, notes "Reference for Business." Marketing communication strategy defines the business's plan for product information dissemination and brand awareness development. Businesses employ five general marketing communication strategies. Company owners often inspire customer trust by presenting the personal story that led to the business's creation. A business clearly presents its products, along with projected customer benefits. The business illustrates why its product is superior to similar competitors' products. A company utilizes customer testimonials to highlight a product's value. A business often creates customer goodwill by developing an informational sheet on a customer-focused topic.

\subsubsection{Components of Marketing Communication}

1) The Foundation is based on a strategic understanding of the product and market. This includes changes in technology, buyer attitudes and behavior and anticipated moves by competitors. 2) The Corporate Culture increasingly brands are seen as indivisible from the vision, capabilities, personality and culture of the corporation. 3) The Brand Focus is the logo, corporate identity, tagline, and style and core message of the brand. 4) Consumer
Experience includes the design of the product and its packaging, the product experience (for instance in a retail store) and service. 5) Communications Tools includes all modes of promotion, for example advertising, direct marketing and other communications tools including social media. 6) Promotional Tools trade promotions; consumer promotions; personal selling, database marketing, and customer relations management; public relations and sponsorship programs. 7) Integration Tools software that enables the tracking of customer behavior and campaign effectiveness. This includes customer relationship management (CRM) software, web analytics, marketing automation and inbound marketing software.

\section{Advertising, Sale Promotion and Public Relation.}

\subsection{Advertising}

"Paid form of non personal communication about an organization or its products that is transmitted to a target audience through a mass/broadcast medium"

\subsection{Use of Advertising in LIS marketing:}

\subsubsection{Promoting Products or Organizations}

Institutional Advertising promotes organizations, images, ideas or political issues. IE Beer Company sponsors responsible drinking to promote the company image. Product Advertising promotes goods and services.

\subsubsection{Stimulating Primary and Selective Demand}

First to introduce product needs to stimulate primary demand. Pioneer Advertising informs people about the product (introduction stage of the product life cycle). Do not emphasize the brand name.

\subsubsection{Offsetting Competitors Advertising}

Defensive advertising, offset to lessen the effect of competitors advertising. extremely competitive consumer products markets.(Used in fast-food industry)

\subsubsection{Making salespersons more effective}

Tries to resell product to buyers by informing them of uses, features and benefits- encourage them to contact dealers etc.

\subsubsection{Increasing use of product}

Consumer can consume only so much of a product, this limits absolute demand. May need to convince the market to use the product in more than one way.

\subsubsection{Reminding and reinforcing customers}

Reminder, need to keep company/product name at the forefront of consumers' minds in the competitive marketplace. Reinforcement prevents cognitive dissonance.

\subsubsection{Reducing Sales fluctuations}

Increase sales during slow periods will help increase production efficiency; IE advertising reduced prices of lawn mowers in the winter months (reduce inventory costs).

\subsection{Sale Promotion}

“To communicate with individuals, groups or organizations to directly or indirectly facilitate exchanges by informing 
and persuading one or more audiences to accept an organization's products"

Sales Promotion Opportunities

1) Increase in sales by providing extra incentive to purchase.

2) Objectives must be consistent with promotional objectives and overall company objectives.

3) Balance between short term sales increase and long term need for desired reputation and brand image.

4) Attract customer traffic and maintain brand/company loyalty.

5) Reminder functions-calendars, T Shirts, match books etc.

6) Impulse purchases increased by displays

7) Contests generate excitement esp. with high payoffs.

\subsection{Public relation}

Companies cannot survive in isolation they need to have a constant interaction with customers, employees and different stakeholders. This servicing of relation is done by the public relation office. The major function of the public relation in marketing LIS to: To handle press releases, To support product publicity, To create and maintain the corporate image, To handle matters with lawmakers, To guide management with respect to public issues, To support corporate and product branding activities

\section{Marketing techniques in Library management: Future viewpoints}

11.1 Body of specialized knowledge and technical skills; library profession required specialized knowledge and technical skill, therefore marketing techniques provides technical skills set for future library manager

11.2 Formal training and experience; it required serious preparation for acquiring the necessary knowledge and method for applying knowledge for work and technical skills with high qualification thus, marketing is useful for library management and it can be useful in library future.

11.3 An ethical code or standard of conduct; marketing management is useful for library, in this regard there should ethical code and standard conduct according to marketing method to provide quality services to the user and manager of the library within the available budget of library.

11.4 A commitment to public service rather than to monetary gain; the marketing management values teach that the main aim being to reduce public services, therefore, it is required that its members should regard services than monetary gain. Librarianship as a service profession therefore the users are regarded as the king.

11.5 Financial return not the measure of success; financial return is not regarded as a measure of success, according to marketing management philosophy, changing value of library professionals have sometimes given more value to financial return when this is not desirable.

\section{References}

[1] Dworkin, Kristine. (2003). Internal marketing: Breaking the barriers, In: An Integrated approach to services marketing: a book of readings for library and information services, Edited by Dinesh K. Gupta and Ashok Jambhekar, Mumbai: Allied, 272-278.

[2] Freeman, James E and Ruth M. Katz. (1978). Information marketing In: Annual Review of Information Science and Technology, 13, White Plains, New York: Knowledge Industry Publications Inc.

[3] Hiremath, C.V. (2003). Marketing of library and information products and services: A study in designing economic models with reference to capital markets in India. (PhD. thesis) submitted to Karnatak University Dharwad, (Unpublished)

[4] Norman, O.Gene. (1989). Marketing library and information services: an annotated guide to recent trends and developments. Reference Services Review 17, no. 1: 43-64.

[5] Renborg, Greta. (1997). Marketing library services: how it all began, Proceedings of the 63rd IFLA General Conference (CD-ROM)

[6] Tees, Miriam, H. (1993). Teaching management to information professionals: a practical approach guidelines for instructors, IFLA Journal, Vol.19, no.3:292-321

[7] Tucci, Valerie K. (1988). Information marketing in libraries, In: Annual Review of Information Science and Technology, Vol. 23, BV Elsevier Science Publishers for ASIS

[8] UNESCO, (1988). Guidelines for the teaching of marketing in the training of Librarians, Documentation officers, and Archivists. Paris: UNICCO

\section{Author Profile}

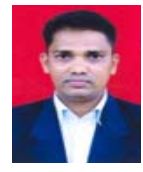

Mr. Prakash Dongardive, writing my own biography in the context of contribution of my study, experiences, and publication in LIS sector, which would be beneficial for future library and Information Science students as well as students and professionals from other branches of knowledge. I born in 15 June 1976, at 'Mera BK' a small town of India located in the state Maharashtra. I could not see my parents, I lost them when I was just six months old, my brother look after me, and he is the only source of my growth and inspiration. My educational qualification is M.A. Sociology, M. Lib. and Information Science, from Nagpur University, MS, India, and pursuing research at University of Pune, on "Use of online journals by the faculty members of science streams in University of Pune" I have earned a certificate of information Technology from technical board Mumbai, MS, India. I have knowledge of Greenstone digital library software which is necessary for Library science professionals. In the context of my employment history, I started my work as a Librarian in Dec. 2004 at Dr. Gode college of Education, MS, India, after that I was a Librarian and faculty for college of Library and Information science at Buldhana, MS, India. I also worked as an Electronic Resource Librarian for King Abdullah University of Science and Technology, Saudi Arabia, and presently I am an Asst. professor in Mekelle University, Ethiopia. Research and publication is the back bone of every branches of knowledge in academic field and Library and Information is not apart from it, today there are many researches going on in LIS, and I also would like to my contribution to my respected field. I have published a research paper with IGI Global in IJIRR, present book is very useful for "Electronic Resources and their Management" in the context of managing online journals, I am most gratified to place in the hand of the teachers and students of Library and Information Science, which would be beneficial for them. I would be busy in the contribution for Library and Information science in my future. 